\title{
Pre-service Science Teachers' Images and Misconceptions of Atomic Orbital and Self-ionization Concepts
}

\author{
Gülseda Eyceyurt Türk ${ }^{1, *}$, Ümmüye Nur Tüzün \\ ${ }^{1}$ Chemistry Education Department, Faculty of Education, Cumhuriyet University, Turkey \\ ${ }^{2}$ Science and Art Center, Education of the Gifted, Ministry of National Education, Turkey
}

Copyright $\bigcirc 2018$ by authors, all rights reserved. Authors agree that this article remains permanently open access under the terms of the Creative Commons Attribution License 4.0 International License

\begin{abstract}
The purpose of this study was to uncover pre-service science teachers' images and misconceptions regarding atomic orbital and self-ionization concepts. This study involved a total of 68 pre-service science teachers working at a public university during the 2015-2016 academic year. In this qualitative study, data were collated with the use of worksheets that participating teachers completed by drawing and explain the concepts regarding atomic orbital and self-ionization concepts. Collated data were then subject to content analysis. The results of this study showed that participants' images about atomic orbital and self-ionization concepts were insufficient and that pre-service science teachers hold various misconceptions about orbital and self-ionization concepts. The reasons of the misconceptions could be backed by the pre-service science teachers' inadequacy regarding the mental construction of proper images of scientific concepts and as a recommendation of the study applications are required for improving pre-service science teachers' scientific concepts images being aware of their inadequacy.
\end{abstract}

Keywords Science Education, Images, Misconceptions, Atomic Orbital Concept, Self-ionization Concept

\section{Introduction}

Properly constructed science lessons should help students to think critically, solve daily life problems and ensure competitiveness in business in later life. Consequently, science teachers must themselves be educated according to a basic understanding that seeks to continually improve their technological-pedagogical fingerprints and the construction of well-designed educational environments. This is only possible when science teachers learn scientifically correct images regarding scientific concepts and hold no misconceptions regarding such images.

Having an image of a concept means holding a conceptual representation of an image in one's mind as a mental picture [1]. For instance, if one holds an image of the crystal form of sodium chloride in one's mind it means that one is able to envisage sodium chloride ions, their ionic sizes, and the ions' electrostatic interactions, as well as the sodium chloride's unit cell structure and the crystal form comprised of these unit cells.

Misconceptions are often referred to as preconceptions because they arise from everyday observations and generalizations that begin in childhood [2]. Properly constructed teaching environments are supposed to help students change their misconceptions and instead form scientifically true ones.

According to the available national literature in the field, science teachers' images regarding alkenes, astronomy, atoms, diffusion, dissolution, electrical circuits, electricity, environment, fermentation, gases, light, mixtures, proteins, solutions, relocation, science, sound, velocity, and work were all insufficient; indeed, science teachers hold various misconceptions about these concepts [3-11]. According to the available international literature in the same field, science teachers' images regarding the circulatory system, chemical equilibrium, physical science, electric current, and seasons were all insufficient and they hold various misconceptions about these concepts just as the national literature [12-16]. In all these researches it was said that if science teachers were not sufficient regarding these concepts, the education of their students regarding such concepts would be insufficient as a result.

This study intends to determine pre-service science teachers' images and misconceptions regarding two uncommon and previously unsearched science concepts, thereby informing and improving higher education 
organization and increase the efficacy of qualified science educators and their students. This research also intends to contribute to existing literature on science teachers' images and misconceptions for the benefit of future further studies; consequently this will inform prospective qualified science teachers regarding their awareness of such images and misconceptions of these uncommon and previously unsearched scientific concepts.

\section{Method}

A qualitative research approach is one that can be identified as one that tries to picture and identify the connection between things and their stories [17]. This qualitative study investigated pre-service science teachers' images and misconceptions about atomic orbital and self-ionization concepts. This study involved a total of 68 pre-service science teachers working at a public university during the 2015-2016 academic year. Worksheets that make teachers draw and explain orbital and the self-ionization concepts were utilized as data collection tools. Data were gathered over the course of a week before being subject to a content analysis. Every participating pre-service science teacher was given 60 minutes to complete the worksheet. The two research authors were responsible for checking the validity of the data collection tools as well as coding and categorizing consistencies to determine the reliability of the data collection tools. The codes and categories were constructed by the two research authors. In other words the codes and categories previously constructed in the literature were not used. Cross-content analysis was also utilized, regardless of whether the categories consisted of all the codes or not [18].

\section{Results}

The data collection tools were used to collate data on how teachers draw and explain the uncommon and previously unsearched scientific concepts. These data were then analyzed and the results of the data analysis categorized according to the following subtitles: 'pre-service science teachers' images of atomic orbital concept', 'pre-service science teachers' misconceptions about atomic orbital concept', 'pre-service science teachers' images of self-ionization concept' and 'pre-service science teachers' misconceptions about self-ionization concept'.

\section{Pre-service Science Teachers' Images of Atomic Orbital Concept}

According to the data, no participants were able to provide scientifically correct images of the atomic orbital concept; $69 \%$ of teachers were able to provide partially correct scientific images about the atomic orbital concept, and $24 \%$ provided incorrect or irrelevant scientific images about the atomic orbital concept. These findings are presented in Table 1.

Table 1. Pre-service science teachers' images of atomic orbital concept*

\begin{tabular}{|c|c|c|}
\hline Categories & $\begin{array}{c}\text { Frequency (f) } \\
\text { Percentages (\%) }\end{array}$ & Example \\
\hline $\begin{array}{c}\text { Scientifically } \\
\text { correct images }\end{array}$ & 0 & - \\
\hline & & \\
$\begin{array}{c}\text { Partly correct } \\
\text { scientific images }\end{array}$ & 47 & \\
\hline $\begin{array}{c}\text { Incorrect or } \\
\text { irrelevant images }\end{array}$ & 16 & \\
& $24 \%$ & \\
\hline
\end{tabular}

*Five pre-service science teachers were unable to draw or explain the concept.

Teachers' drawings that consisted of 'drawing an orbital as a sphere' were categorized as being partly correct scientific images because researchers expected that teachers would be able to draw a probabilistic location for electrons based on modern atomic theory for their images to meet the criteria for inclusion in the scientifically correct images category.

Teachers' drawings that met the following criteria were categorized as incorrect or irrelevant images: 'drawing an 's' orbital as a circle'; 'drawing an 's' orbital as orbits', 'drawing an 's' orbital as a 'p' orbital', and 'drawing a five-dimensional 's' orbital shape'.

\section{Pre-service Science Teachers' Misconceptions of Atomic Orbital Concept}

Participants' depictions of molecular orbital concepts according to data collected from the worksheets and subsequently analyzed showed that participants held several misconceptions including: "s' orbital is not symmetric"' $(\mathrm{f}=10)$; 'Electrons turn around an orbital' ( $\mathrm{f}=$ 2); '[an] 's' orbital consists of six electrons' ( $\mathrm{f}=2$ ); 'Atoms do not have a nucleus' $\mathrm{f}=2$ ); and 'elements settle in the orbital' ( $\mathrm{f}=1)$.

Examples of teachers' drawings and the corresponding explanations from teachers can be seen depicted in Figures 1,2 and 3 .

As can be from the drawing (Figure 1), the teacher's understanding was insufficient to draw a probabilistic location for electrons based on modern atomic theory; the teacher's explanation and drawing made it clear that the teacher held a misconception - that the "'s' orbital is not symmetric'. 


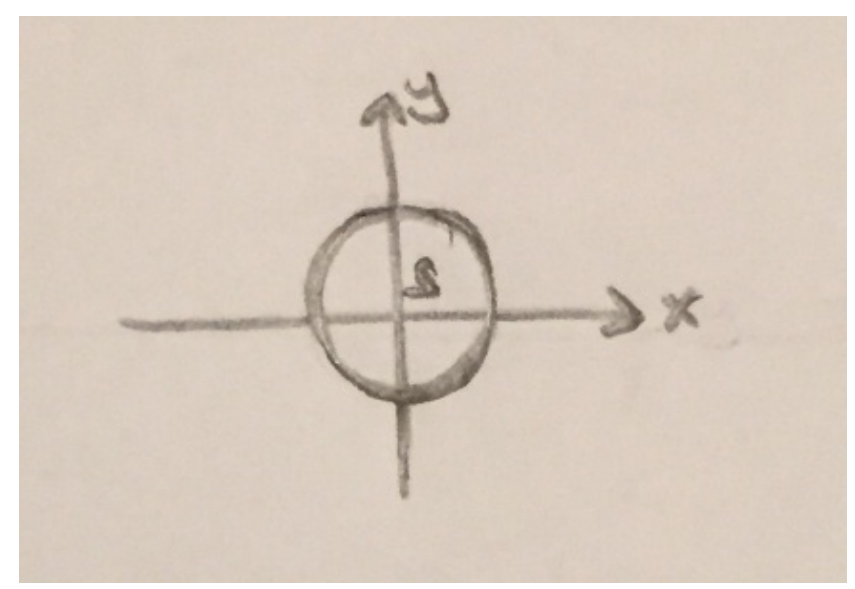

Figure 1. A teacher's drawing and explanation of the atomic orbital concept. The teacher's explanation of the drawing: “'p' orbital doesn't have symmetry because its shape is a sphere."

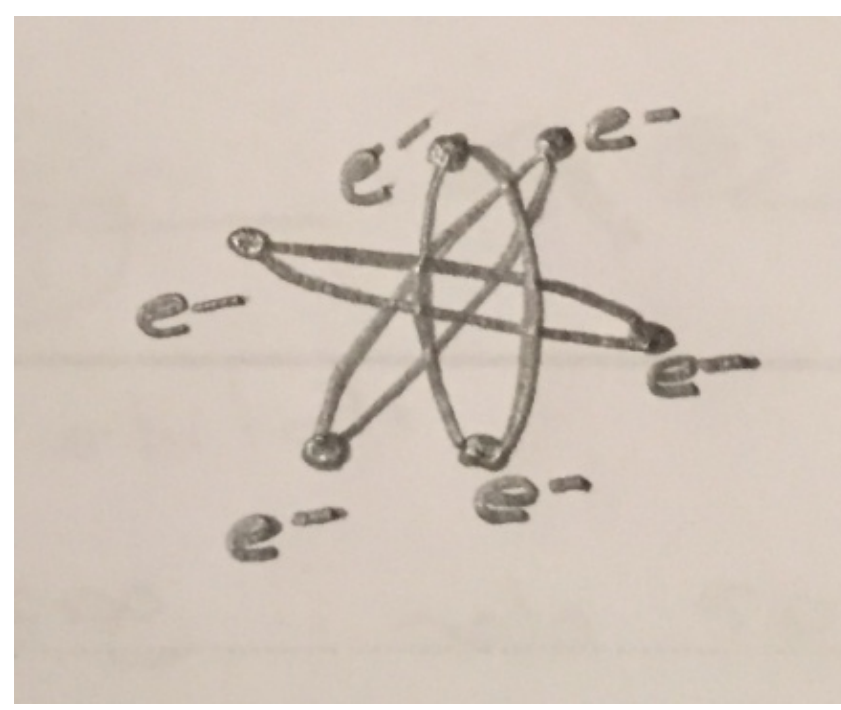

Figure 2. A second teacher's drawing and explanation of the atomic orbital concept. The teacher's explanation of the drawing: "Electrons turn around an orbital."

As can be seen at the drawing (Figure 2), the teacher's understanding was insufficient to draw an accurate ' $\mathrm{s}$ ' orbital. The teacher drew six electrons for a ' $\mathrm{s}$ ' orbital and thus the teacher can be said to have held the misconception that an 's' orbital consists of six electrons'. It can also be seen from the drawing that the teacher held the further misconception that 'atoms do not have a nucleus'. Furthermore, the teacher's explanation of the drawing made it clear that the teacher held the misconception that 'electrons turn around an orbital.'

As can be seen at the drawing (Figure 2), the teacher's understanding was insufficient to draw an accurate ' $\mathrm{s}$ ' orbital. The teacher depiction of the atomic orbital was geometrically incorrect. The teacher's explanation made it clear that the teacher held the misconception that the "s orbital is not symmetric" as the teacher made the assumption as it was symmetric like as a bean.

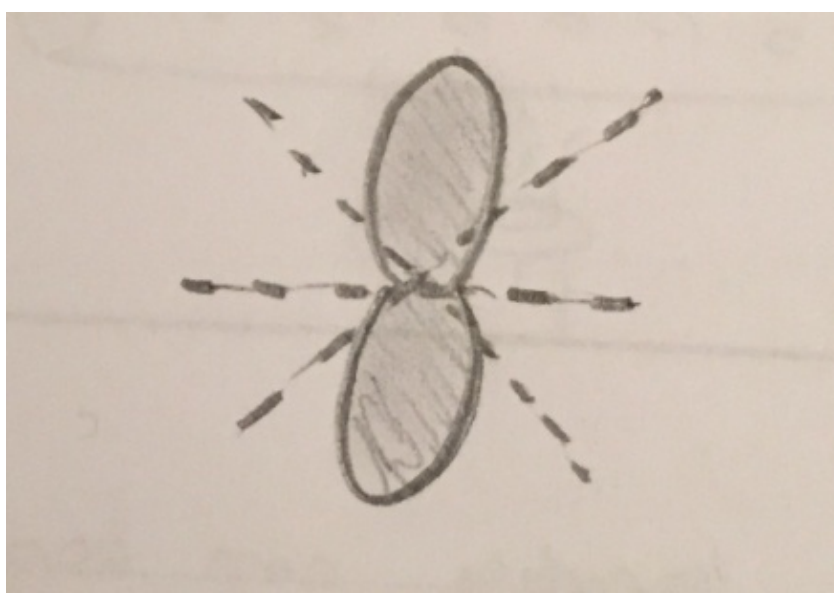

Figure 3. Another teacher's drawing and explanation of the atomic orbital concept. Teacher's explanation of their drawing: "If the orbital was symmetric, then it would look like as a bean."

\section{Pre-service Science Teachers' Images of Self-ionization Concept}

For the self-ionization concept-as is the case for the atomic orbital concept - a result of zero percent was seen from the 'scientifically correct images' category. Overall $49 \%$ of teachers were able to provide partially correct scientific images of the self-ionization concept, while $46 \%$ of teachers provided incorrect or irrelevant scientific images of the same concept. These findings are presented in Table 1.

Table 2. Pre-service science teachers' images of self-ionization*

\begin{tabular}{|c|c|c|}
\hline Categories & $\begin{array}{c}\text { Frequency (f) } \\
\text { Percentage (\%) }\end{array}$ & Example \\
\hline $\begin{array}{l}\text { Scientifically } \\
\text { correct images }\end{array}$ & 0 & - \\
\hline $\begin{array}{c}\text { Partly correct } \\
\text { scientific images }\end{array}$ & $\begin{array}{c}33 \\
49 \%\end{array}$ & \\
\hline $\begin{array}{l}\text { Incorrect or } \\
\text { irrelevant images }\end{array}$ & $\begin{array}{c}31 \\
46 \%\end{array}$ & \\
\hline
\end{tabular}

*Four pre-service science teachers were unable to draw and explain the concept

For the scientifically correct images category, teachers were asked to depict the self-ionization concept using scientifically correct three-dimensional molecule geometries for chemical compounds and ions for the self-ionization reaction, ionic charges for ions, and two-way arrows for the self-ionization reaction. No drawings featured all the correct aspects of such a depiction.

Teachers' drawings that met any of the following criteria were categorized as partly correct scientific images: 'drawing does not accurately depict molecular geometry', 'lack of drawing of ionic charge' 'drawing of extra 
electrons', 'lack of drawing of some electrons', 'drawing of formulization instead of three-dimensional molecular shape' and 'lack of two-way arrows.'

Teachers' drawings that met any of the following criteria were categorized as incorrect or irrelevant images: 'drawing an incorrect product', 'lack of drawing of any of the products', 'thinking water as $\mathrm{O}_{2} \mathrm{H}$ instead of $\mathrm{H}_{2} \mathrm{O}$ ', 'drawing of a compound with ionic charge', 'drawing of the different atoms as the same size', 'drawing failed to include depiction of molecular bonds', 'drawing only depicts the water formularization', 'drawing only depicts the water's three-dimensional molecular shape', 'forming $\mathrm{H}-\mathrm{H}$ covalent bonds for water' and 'drawing of free hydrogen atoms among water molecules'.

\section{Pre-service Science Teachers' Misconceptions about Self-ionization Concept}

When data collated from the worksheets was analyzed regarding the self-ionization concept, it was found that participants held misconceptions about the concept such as 'during the chemical reactions, atoms stick to each other' (f $=7$ ); 'for the self-ionization of water, chemical reaction means forming hydrogen bonds' ( $f=2)$; 'chemical reaction means interaction' $(\mathrm{f}=1)$; 'chemical reaction means adjunction' ( $\mathrm{f}=1)$; 'molecule or ion is similar to a human' $(f=1)$; 'molecules and ions are the same' $(f=1)$.

Examples of teachers' drawings could be seen in Figures 4, 5 and 6 for backing the findings. The teachers' explanations of their drawings are also presented alongside their drawings.

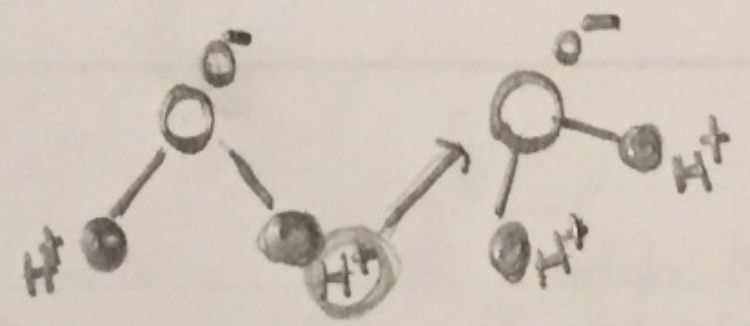

Figure 4. A teacher's drawing and explanation of the self-ionization concept. Teacher's explanation of the drawing: "The hydrogen atom of a water sticks to another oxygen atom of another water."

As can be seen from the drawing (Figure 4), the teacher's understanding was insufficient for drawing the geometric three-dimensional molecule and the self-ionization reaction. The explanation of the drawing made it clear that the teacher held the misconception that 'during the chemical reactions, atoms stick to each other.'

As can be seen at the drawing (Figure 5), this teacher's understanding was insufficient for drawing the geometric three-dimensional molecule and the self-ionization reaction. The explanation of the drawing made it clear that the teacher held the 'chemical reaction means adjunction', and 'molecules and ions are the same' misconceptions.

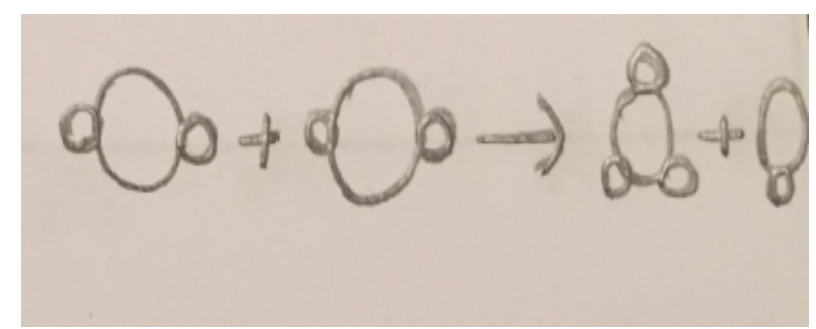

Figure 5. A second teacher's drawing and explanation of the self-ionization concept. The teacher's explanation of the drawing: "Two water molecules adjunct with each other."

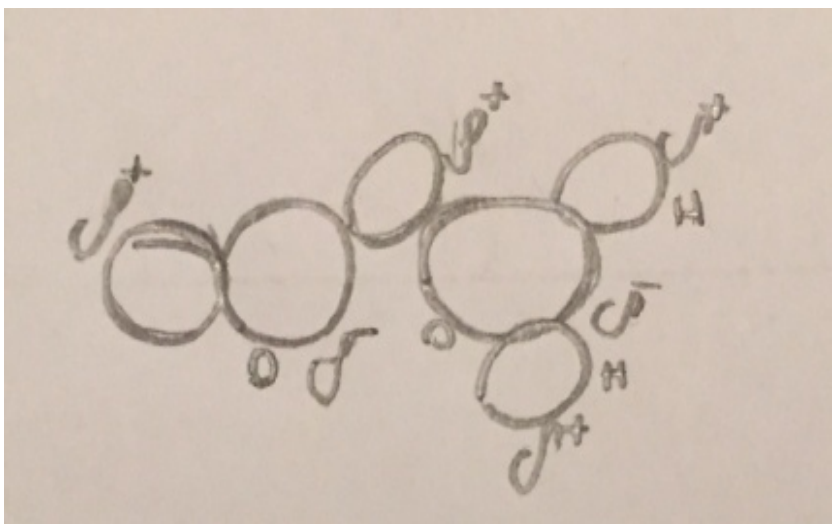

Figure 6. Another teacher's drawing and explanation of the self-ionization concept. The teacher's explanation of the drawing: "There are partly negative and partly positive charges of the water molecules. When the water molecules come closer to each other, the molecules interact."

As can be seen from the drawing (Figure 4), this teacher held the 'chemical reaction means interaction' misconception. During the uncovering of the misconception, the teacher's explanation can be given as a premise for the kind of the misconception; that is, the teacher held a conception that image of intermolecular interaction of water instead of reaction.

\section{Conclusions and Discussion}

This study found that pre-service science teachers' images regarding atomic orbital and self-ionization concepts were insufficient, and that pre-service science teachers held various misconceptions regarding these concepts.

Existing literature in the field emphasized that some students do not learn chemistry because they struggled and were unable to draw scientifically accurate and correct images of the submicroscopic nature of the chemical concepts [19]. The current study corroborates this in finding that pre-service science teachers did not hold scientifically accurate images of orbital and self-ionization concepts due to their lack of understanding of these 
concepts' submicroscopic nature.

Images regarding a concept are formed in the mind when an individual hears, envisages or conceives of a particular concept. For example, when one conceives of iron this means that one pictures or envisages an iron atom's core and its electrons, atomic shape, atomic size and metallic structure in scientific terms [20]. Consequently, the findings of this study have shown that pre-service science teachers' concepts were insufficient when envisaging and picturing a holistic mental image regarding atomic orbital and self-ionization concepts.

This study included an in-depth assessment of two-atomic orbital and self-ionization-scientific concepts; this triangulation which would make the findings more reliable by featuring different aspects of different scientific concepts to the reader. In other words, through a triangulation of two different means of portraying/assessing individual teachers' understanding of certain concepts the understanding of the reader could be more effectively scrutinized.

One of the misconceptions identified in this study corroborates a misconception highlighted by relevant literature in the field; namely, the misconception that a 'molecule or ion is similar to a human' corroborates the misconception featured in the literature that 'atoms are alive' [21-22].

In conclusion, the researches findings suggest that, in order to produce and educate qualified science teachers, academics must be aware of pre-service science teachers' inadequacy regarding the mental construction of proper images of scientific concepts. Consequently, these individuals should be taught in educational environments at universities that ensure the construction of proper mental images regarding scientific concepts. By ensuring that science teachers are qualified and educated in the correct manner regarding these concepts, the education of their students regarding such concepts is assured as a result.

\section{Recommendations and Limitations}

Based on the findings of this research, the authors recommend that more research is required on this subject. Specifically the authors recommend that future studies investigate concept images of pre-service science teachers so that, prospectively, more technologically and pedagogically qualified teachers can be trained in regard to this subject.

The limitation of the study was that no application was done for enhancing pre-service science teachers' scientific concepts images. For further studies applications are required for improving pre-service science teachers' scientific concepts images being aware of their inadequacy, and misconceptions.

\section{REFERENCES}

[1] Mackenzie, A. A., \& White, R. T. (April 13-17, 1981). Fieldwork in geography and long term memory structures. Paper presented at Annual Meeting of the American Educational Research Association, Los Angeles.

[2] Styer, D. F. (1996). Common misconceptions regarding quantum mechanics. American Association of Physics Teachers, 64(1), 31-34.

[3] Ayvacı, H. Ş., \& Şenel Çoruhlu, T. (2012). Fen ve teknoloji ögretmen adaylarının bilim ve fen kavramları ile ilgili sahip oldukları görüşlerin araştırılması. Dicle Üniversitesi Ziya Gökalp Ĕ̈itim Fakültesi Dergisi, 19, 29-37.

[4] Değirmenci, S., Bacanak, A., \& Karamustafaoğlu, O. (2012, Haziran). Fen bilgisi öğretmen adaylarının ışık konusundaki kavram yanılgıları. X. Ulusal Fen Bilimleri ve Matematik Eğitimi Kongresi'nde sunulmuş bildiri, Ömer Halisdemir Üniversitesi, Niğde.

[5] Duman, M. Ş., \& Avcı, E. (2014). Fen ve teknoloji eğitiminde kavram yanılgıları üzerine 2003-2013 yılları arasında yapılmış çalışmaların değerlendirilmesi.Fen Bilimleri Ögretimi Dergisi, 2(2), 67-82

[6] Erduran Avc1, D., Kara, İ., \& Karaca, D. (2012). Fen bilgisi öğretmen adaylarının iş konusundaki kavram yanılgıları. Pamukkale Üniversitesi Ĕ̈itim Fakültesi Dergisi, 31, 27-39.

[7] Eyceyurt Türk, G., Akkuş, H., \& Tüzün, Ü. N. (2014). Fen bilgisi öğretmen adaylarının çözünme ile ilgili imajları. Erzincan Üniversitesi Eğitim Fakültesi Dergisi, 16(2), 65-84.

[8] Khalid, T. (2001). Pre-service teachers' misconceptions regarding three environmental issues. Canadian Journal of Environmental Education, 6, 102-120.

[9] Kırbaşlar, F. G., Çıngıl Barıș, C.., \& Ünal, M. (2009). Fen bilgisi öğretmen adaylarının fermantasyon konusundaki yanlış öğrenmelerinin araştırılmasına yönelik bir çalışma. Hacettepe Üniversitesi Eğitim Fakültesi Dergisi, 36, 158-168.

[10] Türk, C., Kalkan, S., Bolat, M., Akdemir, E., Karakoç, Ö., \& Kalkan, H. (2012). Fen ve teknoloji ögrretmen adaylarının temel astronomi kavramlarını kavrama düzeyleri üzerine bir durum çalışması. Ĕgitim ve Öğretim Araştırmaları Dergisi, $1(2), 202-209$

[11] Yildırım, O., Nakiboğlu, C., \& Sinan, O. (2002, Eylül). Fen bilgisi ögretmen adaylarının difüzyon ile ilgili yanlış kavramalarl. V. Ulusal Fen Bilimleri ve Matematik Eğitimi Kongresi'nde sunulmuş bildiri, Orta Doğu Teknik Üniversitesi, Ankara.

[12] Yip, D. Y. (1998). Teachers' misconceptions of the circulatory system. Journal of Biological Education, 32(3), 207-215.

[13] Banerjee, A. C. (1991). Misconceptions of students and teachers in chemical equilibrium. International Journal of Science Education, 13(4), 487-494.

[14] Lawrenz, F. (1986). Misconceptions of physical science concepts among elementary school teachers. School Science and Mathematics, 86(8), 654-660. 
[15] Webb, P. (1992). Primary science teachers' understandings of electric current. International Journal of Science Education, 14(4), 423-429.

[16] Atwood, R. K., \& Atwood, W. A. (1996). Pre-service elementary teachers' conceptions of causes of seasons. Journal of Research in Science Teaching, 33(5), 553-563.

[17] Glesne, C. (2012). Nitel araștırmaya giriș. A. Ersoy \& P. Yalçınoğlu (Çev. Ed.). Ankara: Anı Yayıncılık.

[18] Erickson, E. (2004). Demystifying data construction and analysis. Anthropology and Education, 35(4), 486-493.

[19] Nakhleh, N. B. (1992). Why some students don't learn chemistry. Journal of Chemical Education, 69, 191-196.

[20] Atasoy, B. (2004). Fen ögrretimi ve ögrenimi. Ankara: Asil Yayın Dağıtım.

[21] Canbolat, N., Pınarbaşı, T., Bayrakçeken, S., \& Geban, Ö. (2004). Kimyadaki bazı yaygın yanlış kavramalar. Gazi Üniversitesi Gazi Eğitim Fakültesi Dergisi, 24(1), 135-146.

[22] Tezcan, H., \& Salmaz, Ç. (2005). Atomun yapısının kavratılmasında ve yanlış kavramaların giderilmesinde bütünleştirici ve geleneksel öğretim yöntemlerinin etkileri. Gazi Üniversitesi Gazi Eğitim Fakültesi Dergisi, 25(1), 41-54. 